www.jmscr.igmpublication.org Impact Factor 5.244

Index Copernicus Value: 83.27

ISSN (e)-2347-176x ISSN (p) 2455-0450

crossref DOI:_http://dx.doi.org/10.18535/jmscr/v4i8.19

\title{
Tobacco Usage And Awareness Among Adolescence In Chennai Population
}

\author{
Authors \\ T.Nandhini ${ }^{1}$, Dr Madhusudhan ${ }^{2}$ \\ ${ }^{1}$ Saveetha Dental College and Hospital \\ ${ }^{2}$ Department of Pedodontics, Saveetha Dental College and Hospital
}

\section{ABSTRACT}

Aim:

- To estimate the awareness of tobacco abuse among adolescents in chennai population.

Background: Tobacco is one of the leading cause for oral cancer.Tobacco use amongst adolescent is already pandemic and adolescents are vulnerable targets for tobacco use.

Materials and Methods: This study was a population based cross-sectional study conducted in higher secondary schools of Chennai among 100 students belonging to the classes VIII, IX, X, XI and XII with no interventions. Primary outcome measurements were use, knowledge and awareness regarding the risk of tobacco. Following this proportions, statistical analysis were used.

Results: In a population of 100 students , 60(60\%) have used either one of the tobacco products irrespective of time and frequency in a lifetime out of which 35(35\%) belonged to the urban government school and 25 (25\%) belong to the rural counterparts. More than two-thirds of the respondents expressed a desire to quit substance abuse and 55\% had tried to quit. 'Addicted to tobacco 'and 'relief from tension' were the most frequent reasons for continuation of substance use. Level of knowledge on harmfulness of substance use among students was very high (urban - $-84.6 \%$ and rural - 61.5\%) and they stated cinema and friends are the most frequent source information.

Conclusions: In Spite of being aware of the harmful effects of substance use, adolescents take up the habit. This requires comprehensive prevention and control programs in schools and the community, targeted toward adolescents and their parents and other family members. Effective measures are required to encourage shaping the attitude of school children toward self-confidence and adequacy, and also to prevent risky behaviour among adolescents.

Keywords: Attitude, knowledge, rural, substance use.

\section{INTRODUCTION}

Use of tobacco, alcohol and other substances is a major health and social problem worldwide and also affects many children and adolescents. In India, the deaths recognised by tobacco are expected to rise from $1.4 \%$ (1990) to $13.3 \%$ by
$2020^{(1)}$. Young population frequently develop the habit of smoking, which typically becomes a routine practice and turns into a strong addiction. The Global Youth Tobacco Study (GYTS) has reported that smoking is the predominant form of tobacco consumption among adolescents in 
developed countries while both smoking and smokeless tobacco consumption (Smokeless tobacco is unburnt tobacco which is placed into the oral cavity) are prevalent in developing countries ${ }^{(2)}$. According to Indian Global School Personnel Survey, $200{ }^{(3)}$ nearly 1 in 10 school students in the age group of 13 - 15 years smoked cigarette and half of the smokers reported they initiated smoking before the age of ten years. Prevalence of smoking was $2.1 \%$ among the boys and $1.7 \%$ among the girls in Jaipur, ${ }^{(4)} 12.2 \%$ among the boys and $10.2 \%$ among the girls in Noida, ${ }^{(5)} 17.8 \%$ among the boys and $7.3 \%$ among the girls in Deralakatte, Karnataka State ${ }^{(6)}$. The hope that simple information given through educational programs will be adequate to prevent drug dependence is frequently expressed, however, there is no confirmation to support it and there are many reasons to doubt it.Knowledge with regard to the penalty of substance use among adolescents to prevent them from initiating and continuing its use is a question that needs to be clarified further ${ }^{(7)}$. Shaping the approach of children and promotion of a healthy lifestyle, including constructive behaviour is essential in the formative years of life.Therefore, keeping in focus the research question - What is the level of knowledge and attitude held by the users with regard to harm of substance use? - we have formulated the objective of our study, which is to consider the knowledge and to obtain information about the attitude among high school students.

\section{MATERIALS AND METHODS}

This study was a population-based, cross-sectional study, conducted on 100 students in classes VIII, IX, X, XI and XII in higher secondary schools, selected by multistage random sampling, in Chennai, India, with no interventions. A selfadministered anonymous questionnaire was made. From the experience of the researchers in this field, we concluded that:

a) The appreciative level of the students of class VIII onward, allows the administration of a self- administered questionnaire, young students might not understand the questionnaire, which could give rise to false responses and low response rates. b) Initiation of substance use usually begins at the age of 13- or 14 years.

c) Students of these age groups are usually present in class VIII, IX, X,XI and XII

d) Similar studies on student population have been carried out from class VIII onward.

Therefore the classes chosen correspond to an ideal population for this study. Main conclusion measures were substance use, knowledge and awareness regarding to risk of tobacco use.

\section{STATISTICAL ANALYSIS}

The data collected were thoroughly checked and entered into Excel spread sheets and analysis was carried out .The procedures involved were transcription, preliminary data inspection, content analysis, and interpretation.

\section{RESULTS}

Full information on age, gender and participant's use of tobacco product was available for 100 students. This data has been analysed.

Table 1: Demographic details of the study population:

\begin{tabular}{|l|l|}
\hline Age in years & Percentage \% \\
\hline $12-13$ & 9 \\
\hline $13-14$ & 20 \\
\hline $14-15$ & 39 \\
\hline$>15$ & 32 \\
\hline
\end{tabular}

In table 1,It is the age wise distribution of the study population: Majority (39\%)of the study population were in the age group of 14-15 years,followed by 15 years and above(32\%) ,followed by $13-14$ years $(20 \%)$, followed by 12 13 years $(9 \%)$. 
Table 2: Distribution of users according to gender wise:

\begin{tabular}{|l|l|}
\hline Gender & Percentage \% \\
\hline Male & 56.3 \\
\hline Female & 43.7 \\
\hline
\end{tabular}

In table 2, there is the gender wise distribution of the study population of which majority of the population ( $56.3 \%$ ) were males and $43.7 \%$ were females.

Table 3 : Distribution of users based on type of school studying:

\begin{tabular}{|l|l|}
\hline Type of school & Percentage\% \\
\hline Rural government & 45 \\
\hline Urban government & 35 \\
\hline Urban private & 20 \\
\hline
\end{tabular}

In table 3 , is the number of users based on the school of which majority (45\%) of study population was in the rural government, followed by urban government $(35 \%)$, followed by urban private $(20 \%)$.

Table 4: the information regarding the influence of tobacco use:

\begin{tabular}{|l|l|}
\hline Source of information & Percentage\% \\
\hline Popular figures & 25 \\
\hline Friends & 45 \\
\hline Relatives & 30 \\
\hline
\end{tabular}

In table 4 is the information regarding the influence of tobacco use where friends showed a value of $45 \%$ followed by relatives $(30 \%)$ and then popular figures $(25 \%)$

Table 5: Distribution of users according to reason for continuation of substance use:

\begin{tabular}{|l|l|}
\hline $\begin{array}{l}\text { Reason for } \\
\text { continuation }\end{array}$ & Percentage\% \\
\hline To relieve stress & 40 \\
\hline Just an addiction & 35 \\
\hline Unknown reasons & 25 \\
\hline
\end{tabular}

Table 6: Distribution of users according to reason for quitting of substance use:

\begin{tabular}{|l|l|}
\hline Reason for trying to quit & Percentage\% \\
\hline To improve the health & 55 \\
\hline Friends & 30 \\
\hline Relatives & 15 \\
\hline
\end{tabular}

With respect to the reasons for continuation and quitting, there were mixed responses among the urban and rural users. The most frequent reason for continuation was 'relief from tension' (40\%) whereas, 'just an addiction'(35\%) was reported and for 'the unknown reasons'(25\%). The most frequent reasons for quitting both among the urban as well as rural users 'to improve the health' $(55 \%)$,'friends' (30\%) and 'relatives' (15\%).Table 5 and 6

\section{DISCUSSION}

Adolescence is a period of identity forming and handling great pressures. Exposure, experience and behaviour during these formative years can influence lifelong health. Present study has attempted to identify tobacco consumption amongst school and college going students.

In the present study, ever use of substance as well as distribution among the males and females, were comparable to the findings of studies by other authors, ${ }^{(8-10)}$ where we noted similar results with that of other studies.A majority of the users reported trying to end the habit and most of the users expressed a desire to quit the habit. These views were also expressed in other studies, ${ }^{(11-13)}$ which exposed that all users did not want to persist habit and they held a positive attitude toward quitting, therefore, motivation on the part of family, friends, and close ones could help the user to come out of this habit.

Relief from tension has been the most common reason for continuation, followed by addicted to tobacco. These reasons have been cited even by other author ${ }^{(14-20)}$. Factors leading to quitting substance use also exist in and around adolescents, as the major reasons stated were the fear of health problems, which clearly suggests that attitude determining by parents and knowledge of harmfulness of use can indirectly inspire the user to give up the habit. This information has been provided primarily through the media, principally the popular figures like cine actor and sportsmen followed by friends and relatives. Therefore, 
media and close contacts are primarily accountable for imparting knowledge, whether it be pro- or anti-substance use, and these findings are common.

\section{CONCLUSION}

Awareness of the harmful effects of substance use is high. A distressing aspect that has been noticed is that despite having knowledge of substance use, adolescents begin and continue its use. Efforts to manage the problem in this age-group should also intention their parents and other family members, by means of the media. The school being an vital part in a student's life can include and promote an effective and healthy life-style. Interventions that improve parental self-efficacy in conveying and enforcing attitude shaping for their children could diminish adolescent substance use. Healthy substance use control programs, focusing on youth, are essential, to reduce the burden of associated diseases.

\section{REFERENCES}

1. Patel D r. Smoking and children. Indian J Pediatr [serial on the Internet]. 1999[cited 2010 Aug 10]; 66, Number 6:[817-24]. Available from: http://www.springerlink.com/content/14n26144620082p5/

2. Warren c $\mathrm{W}$, riley $\mathrm{L}$, Asma $\mathrm{S}$, Eriksen $\mathrm{m}$ P, Green L, Blanton c et al. Tobacco use by youth: a surveillance report from the Global Youth Tobacco Survey; Bulletin of World health Organization; World health Organization. 2000.

3. Sinha DN. India Global School Personnel Survey (GSPS) 2006. [1-15]. Available from:

http://www.searo.who.int/LinkFiles/GSPS _Report-India.pdf

4. Singh V, Gupta r. Prevalence of Tobacco Use and Awareness of risks Among School children in Jaipur. JAPI [serial on the Internet]. 2006 Aug [cited 2009 April
12]; 54:[609-12]. Available from: http:// www.japi.org/august2006/O-609.pdf

5. Narain r, Sardana S, Gupta S, Sehgal S. Age at initiation and prevalence of tobacco use among school children in Noida, India: A cross-sectional questionnaire based survey. Indian $\mathrm{J}$ med res [serial on the Internet].2011 mar [cited 2009 Nov 12];133:[300-7]. Available from: http:/ /www.icmr.nic.in/ijmr/2011/march/0309.p df

6. Shenoy rP, Shenai PK, Panchmal GS, Kotian Sm. Tobacco use among rural schoolchildren of 13-15 years age group: A cross- sectional study. Indian J Community Med 2010;35:433-35.

7. Older J. Anti - smoking language that the young understand. World Health Forum. 1986;7:74-8.

8. Madu SN, Matla MQ. Illicit drug use, cigarette smoking and alcohol drinking behaviour among a sample of high school adolescents in the Pietersburg area of the Northern Province, South Africa. J Adolesc. 2003;26:121-36.[PubMed]

9. Chen KT, Chen CJ, Fagot-Campagna A, Narayan KM. Tobacco, betel quid, alcohol, and illicit drug use among 13- to 35-year-olds in I-Lan, rural Taiwan: prevalence and risk factors. Am J Public Health. 2001;91:1130-4.[PMC free article] [PubMed]

10. Sutherland I, Willner P. Patterns of alcohol, cigarette and illicit drug use in English adolescents. Addiction. 1998;93:1199-208. [PubMed]

11. Mpabulungi L, Muula AS. Tobacco use among high shool students in Kampala, Uganda: questionnaire study. Croat Med J. 2004;45:80-3. [PubMed]

12. Sutherland I, Shepherd JP. Adolescents' beliefs about future substance use: a comparison of current users and non-users 
of cigarettes, alcohol and illicit drugs. J Adolesc. 2002;25:169-81. [PubMed]

13. Franco JA, Pérez Trullén A, García A, Marrón R, Clemente ML, Rubio E. Tobacco use among young people in informal education settings: a survey of behaviors and opinions. Arch Bronconeumol. 2004;40:10-6. [PubMed]

14. Komro KA, Maldonado-Molina MM, Tobler AL, Bonds JR, Muller KE. Effects of home access and availability of alcohol on young adolescents' alcohol use. Addiction.2007;102:1597-608. [PubMed]

15. Sargent JD, Beach ML, Dalton MA, Mott LA, Tickle JJ, Ahrens MB, et al. Effect of seeing tobacco use in films on trying smoking among adolescents: cross sectional study. BMJ. 2001;323:1394-7. [PMC free article] [PubMed]

16. Kwamanga DH, Odhiambo JA, Amukoye EI. Prevalence and risk factors of smoking among secondary school students in Nairobi. East Afr Med J. 2003;80:207-12. [PubMed]

17. Maziak W, Mzayek F. Characterization of the smoking habit among high school students in Syria. Eur J Epidemiol. 2000;16:1169-76. [PubMed]

18. Sinha DN, Gupta PC, Pednekar M. Tobacco use among students in Bihar (India) Indian J Public Health. 2004; 48:111-7. [PubMed]

19. Singh V, Gupta R. Prevalence of tobacco use and awareness of risks among school children in Jaipur. J Assoc Physicians India. 2006;54:609-12. [PubMed]

20. Sinha DN, Roychowdhury S. Tobacco control practices in 25 schools of West Bengal. Indian J Public Health. 2004; 48:128-31. [PubMed] 